\title{
“WHEN A NATION HAS NO LEADER, POETS BECOME ITS LEADERS" (UKRAINIAN INDIGENOUS LITERATURE AS VIEWED BY YEVHEN MALANIUK THROUGH A MYTHOLOGICAL PRISM)
}

\author{
OLHA SLONOVSKA
}

\begin{abstract}
The article discusses the literary-critical and national political activity of the outstanding Ukrainian poet and states figure Yevhen Malaniuk, using a corpus of his literarycritical essays. The author analyzes the oeuvre of diasporic writers in comparison with that of indigenous Ukrainian poets and prosaists who lived under the yoke of ideological prejudices and persecutions of the Soviet era, a symbiosis of "socialist realism" with stillborn "modernism". Yearning for their homeland, Ukrainian diasporic writers created images of Ukraine the Vision, Ukraine the Dream, Ukraine the Goal, and an ideological political myth of a nation state. Yevhen Malaniuk fulfilled this philosophical and political objective brilliantly. His mythological thinking generated the concept of Ukraine the Hellas as a phenomenon of global importance. From his perspective, only by the glorious heroics of patriots and passionaries is it possible to foster national awareness. However, even with titans such as Taras Shevchenko, Bohdan Khmelnytskyi, Ivan Mazepa, and Symon Petliura, Ukrainian society was nevertheless unable to grasp such heroic endeavors adequately. Outstanding Ukrainian cultural activists never succeeded in viewing reality from a critical perspective. The poet debunks Russian colonialism and castigates Russian proimperial literature, the "split" Hohol, the chauvinistic propaganda of Russian culture. Yevhen Malaniuk's oeuvre is seen as occupying a unique role in our literature.
\end{abstract}

Keywords: conception of Ukraine, state awareness, national idea, national mentality, Russian imperialism, mythological thinking, Ukrainian culture, literary-critical essays.

\section{INTRODUCTION}

A special cohort of Ukrainian writers of the early-to-mid 20th century (first and foremost Yevhen Malaniuk, Oleh Olzhych, Ulas Samchuk, Todos Osmachka, Ivan Bahrianyi, Vasyl Barka), who are regarded as creators of the Ukrainian literary modernist diaspora, constituted the backbone of Ukrainian culture since their stoicism eliminated the possibility of the Ukrainian nation bowing under the intolerable yoke of adversity.

The consolidating vitalistic literary myth of a future Ukraine created by this cohort of writers is a unique, albeit non-accidental, phenomenon. At that time, Ukrainian indigenous literature was a priori incapable of such a surge, not in the least because it was lacking in literary masters. On the contrary, the pen of indigenous Ukrainian masters (such as the fearless novella writer Mykola Khvylovyi; the unique author of Soniachni Klarnety (Clarinets of the Sun) Pavlo Tychyna; the phenomenal pioneer of the Ukrainian poetic cinema Oleksandr Dovzhenko, whose ideas were implemented by Serhii Paradzhanov in as late as the 60s; 
the erudite writer Pavlo Zahrebelnyi) was much sharper, more virtuosic and precise than that of all the above-mentioned diasporic writers. The main reason was a monstrous symbiosis of "socialist realism" with "stillborn" modernism, which was formed because the latter was killed in embryo by Soviet literary criticism with the help of numerous bans, threats, warnings, censorship.

\section{ANALYSIS AND DISCUSSION}

Ukrainian diasporic writers, in contrast to their indigenous contemporaries, experienced a constant yearning for their homeland, idealized their nation and their never-attained nation state. As a result, their literary texts abounded in images of Ukraine the Vision, Ukraine the Dream, Ukraine the Goal. In other words, those writers were only a short step from a literary myth of their nation state.

Ideological political myths of nation states always stem metaphorically from their state hymns. Such a primary artistic expression of a national idea gives a push to creating an artistic myth in national literature, culture, and various kinds of national art in general. In the life of a state, much depends on its hymn, its national idea. It is a sort of a natal chart that reveals a nation's present and future events, an unstoppable paradigm which is unlikely to deviate from its course. Even in colonial superpowers, there is a succession from an ideological political myth to a national literary one. Recalling the "gathering of lands" by the Russian Empire and by its successor, the USSR, or even by present-day Putin's Russia will suffice to visualize the archetypal ideological political myth of this superstate. Hitler's Nazi Germany also created its own ideological political myth of an "Aryan race of superhumans", German "blonde beasts", who were going to have the entire world at their beck and call.

The literary myth of a nation state, of one that does not actually exist on the global map, is preceded by the emergence of the ideological political myth. Taras Shevchenko created a literary myth of Ukraine under the influence of Mykola Kostomarov's ideological political myth of Ukraine vividly visualized in his work "Zakon Bozhyi": knyhy buttia ukrainskoho narodu ("Divine Law": Books of the Genesis of the Ukrainian People). (1845-1846). Taras, Kostomarov's groomsman, together with the other members of the Brotherhood of Saints Cyril and Methodius, was one of the first readers of the manuscript. It had a uniquely phenomenal impact on Shevchenko. Had it not been for M. Kostomarov's "Zakon Bozhyi", Shevchenko would hardly have written Son (A Dream), Yeretyk (The Heretic), I mertoym, i zhyoym... (To the Dead, the Living...), Velykyi Lokh (A Great Vault), or the poems about the gangster-like rampage of Haidamaky (Haidamaks), about social class conflicts between "landowners" and "serfs", or about women's tragedies I був би в нас Тарасик-малорос, / A так явивсь Шевченко-Українець (And we would have had Tarasyk the Little Russian, / But instead, came into being Shevchenko the Ukrainian) [11, p. 34], a genius and a prophet.

In the 20th century, none of the diasporic Ukrainian philosophers or political scientists managed to create a new ideological political myth of Ukraine, though certain efforts were made by D. Dontsov, V. Lypynskyi, M. Shlemkevych. Quite unexpectedly, Yevhen Malaniuk took up the extremely difficult work of creating a national ideological political myth and, surprising as it was for a poet, fulfilled this philosophical and political objective brilliantly: his essays scrutinize the gains and losses of the best Ukrainian leaders, and his Notatnyk (A Diary) is full of reflections on Ukraine's destiny. Consequently, the USSR stigmatized Ye. Malaniuk as a "Ukrainian fascist", a "bourgeois nationalist"; and V. Sosiura, through his poem Vidpovid (Answer), even challenged him to a one-on-one deadly fight.

While serving as a commander in the Ukrainian People's Army, in the Military Staff of Ukraine, and later as an aide-de-camp to General Vasyl Tiutiunnyk, Yevhen Malaniuk could see the young state dying. The masses did not understand the importance of respecting their national leaders; the ideologists of statehood (V. Vynnychenko, M. Hrushevskyi, M. Drahomanov) could not cope with the practice (the strategy and tactics) of leading a liberation movement even in theory, nor did they distinguish between insiders and outsiders or recognize the enemy under the guise of an elder brother. Moreover, the sacred national idea was disregarded by too many to hope for success: "There were huge stocks of weapons. There was large human resource. There was territory... But... Nobody... told the 'masses' what Moscow was like... We lost the Liberation Movement. Mind you - we, the 1918-1919 ensigns and lieutenants. Because we had to do everything the Movement required 'by claws and teeth'" [4, p. 117]. In other words, the burden of building statehood fell mainly on the shoulders of the mid-ranking military, not the newly established government of the Ukrainian People's Republic. The national idea and the national ideological political myth did not even come home to most of the representatives of the Ukrainian people. 
For Ye. Malaniuk, the three-year desperate struggle for the establishment and preservation of the Ukrainian People's Republic served as representative material for deprecating reflections on the role of his generation in the tragic fall of the Ukrainian state in the early 20th century. Ye. Malaniuk was explicit about the long-lasting "castration of the nation": on their own land, the Ukrainians "are neither landowners, nor fathers of families - 'we are being liberated'... from everything" [4, p. 58]. From Ye. Malaniuk's perspective, national consciousness is not an innate characteristic. Enemies are constantly stifling it, dishonoring it by ridicule, by bribing and winning over the most talented members of nations. It is possible to wake up national consciousness, of course; however, if it is not there yet or any longer, it will be impossible to convince the people of something they have already been misled to regard as disgusting; it will be impossible to quickly foster national self-sufficiency in an enslaved nation through persuasion or enlightenment alone, only through glorious heroics of patriots and passionaries because, in fact, "it is a unique pulsation of blood; it is the heart, not the head" [4, p. 59]. The meticulous precision of Ye. Malaniuk's metaphors is truly impressive.

Yevhen Malaniuk regarded outstanding political figures and ingenious artists as a sort of demiurges, godlike creators capable of causing a dramatic change for the better or worse. He castigated Russian tsars for building "the prison of nations": В нещасний час, „на зло Європі", / Ваш божевільний деміург / Створив кубло гнилих утопій / 3 туману й крови - Петербург (At a miserable time, 'to spite Europe', / Your insane demiurge / Created a nest of rotten utopias / From fog and blood-Petersburgh) [5, p. 83]. These lines refer to Peter I, who was regarded as the devil incarnate even in his lifetime; the portrayal of the Bolsheviks' leader, however, is not tantamount to that of the first Russian emperor: A там ім'я посмертне «һенін» / Вже обертається 6 "Пempo» (And there, the posthumous name of "Lenin" / Is turning into that of "Peter") [5, p. 54]. Therefore, while discussing the ideology and policy of Russian rulers, Ye. Malaniuk drifts from an ideological political myth to a literary one, first portraying the enemies of Ukraine and of the Ukrainians and only then proceeding to Ukrainian national problems per se.

The mythological thinking of Malaniuk the essayist, which generated, among other things, an image of ancient Ukraine being on a par with highly developed civilizations (ancient Egypt, Hellas or, to a much lesser degree, Rome), became the cornerstone of the future vitalistic literary myth of 20th-century Ukraine conclusively formatted by the writers who witnessed "the bloodied ways of the apostle" [5, p. 32], the most remarkable diasporic Ukrainian poet, without exaggeration. In the detailed article Narysy z istorii nashoi kultury (Sketches of the History of Our Culture), Yevhen Malaniuk argues that the proto-Ukrainian territory belonged to the metropolitanate of the ancient Greeks and regards proto-Ukrainian culture as comparable to highly developed ancient civilizations: "Our land has had too many rulers and names throughout the millennia of its turbulent history... But names do not change the essence of things. What was essential was that there existed an indigenous population (as proved by archaeology) and that in ancient times that population culturally belonged to the Hellenic world" [3, p. 2]. The author describes the important firsts in the worlview and mentality of his Ukrainian contemporaries, direct inheritors of the ancient cultural center. Yevhen Malaniuk bases his conclusions on the ideas of the German thinker and writer of the mid-to-late 18th century, Johann Gottfried Herder, who traveled in Ukraine in 1769: "Ukraine will someday become a new Hellas: this people's splendid land under sunny skies, cheerful disposition, musical talent, fertile soil - will wake up someday. From small tribes, like those of the Greeks, a great cultural nation will come into existence. Its boundaries will extend to the Black Sea, and from there into the wide world" [3, p. 95]. Yevhen Malaniuk warns indigenous Ukrainians against neglecting or making light of "the complex of Hellas" in Ukrainian culture because even the Byzantine Empire as a conglomerate of Hellenic culture and Roman state formation par excellence always regarded Kyiv Rus' as its own important constituent and the phrase "Little Russia" initially referred to the center of Ukraine (Kyiv). The Russian colonizer changed its primary meaning to "an appendage" [3, p. 129], whereas the indigenous population perceived the name in its original meaning, so this "terminology seemed quite natural till as long as the early 19th century and those descendants did not feel anything 'offensive' about it" [3, p. 129]. It was Shevchenko who noticed that Russian colonizers had reframed the original lexical meaning of "Little Russia", so he counterposed it to the term "Ukraine".

According to Yevhen Malaniuk, a person who hides away from God's watchful eye and has no "stimulating fear of God" [2, p. 14] inevitably becomes an apathetic, phlegmatic half-master / half-serf who, having a full stomach, never reflects on his or her status of a slave: Обабіч шляху із Варяг у Греки / Ще й досі 
живуть ні варяги, ні греки, // А так собі, еманація, гра - / Дрижить протоплазмою без ядра. // А скільки не пружили і не палили - Тільки йойкало тлусте тіло. / Тільки переповзало завжди / Тудою - сюди, а сюдою mydu (Either side of the route from the Varangians to the Greeks, I Is still up till now inhabited by neither the Varangians nor the Greeks // But just so-so, emanation, play - / Shaking protoplasmically without a nucleus. /I Whenever forced down or burnt - The thick body only ouched, that was all. / It always only crawled across / From over there - to here, and from over here - to there) [5, p. 235]. It is characteristic that whenever God sends Ukraine titans, for instance Taras Shevchenko, Bohdan Khmelnytskyi, Ivan Mazepa, and Symon Petliura, in an effort to save it, Ukrainian society is nevertheless unable to grasp such heroic endeavors adequately. Psychologically injured by servitude, these people are only capable of neglecting, simplifying everything invaluable and big as a priori incomprehensible and unattainable.

In his essays, Yevhen Malaniuk frequently focuses on such phenomena ("No national enemy would have been able to vulgarize Shevchenko the way the Ukrainian intelligentsia was lucky to do" [2, p. 14]). By contrast, European self-sufficient nations managed to overcome the pubertal period of amorphousness several centuries earlier than Ukraine did; and in the early 20th century for this reason alone, they did not turn into sleazy defenseless "protoplasm" but became hard "crystals" of diamond. Crystal-like firmness helped these states to oppose the threat of assimilation and develop their nationalism.

According to Yevhen Malaniuk, the crystallization of a nation is the final stage in the process of statehood formation; hence, the author regrets to stress the following: "... The time of the actual formation of the Cossack elite was too short for the organic process of crystallizing a new leading class in a new State to be fully complete" [3, p. 118-119]. Therefore, Bohdan Khmelnytskyi was not able to implement his own doctrine of statehood, yet again, through lack of terrestrial time given to him as a human being: "The death of Khmelnytskyi (who was only 62 years old) was the most tragic event of the epoch. It came at the moment of total war with Poland and the finalization of a treaty with Carl Gustav of Sweden, the treaty that would have crossed out the so-called Pereiaslav provisions automatically, thus eliminating in embryo the subsequent malignant and detrimental Pereiaslav legend" [3, p. 119]. At that historic moment, Moscow felt much stronger than democratic Cossack Ukraine did. For this reason, the Russian creeping occupation "smashed the incompletely formed nation of Ukrainians with its horrible weight for long centuries to come" [3, p.119]; therefore, even Ivan Mazepa's long-lasting tireless struggle for the Ukrainian national idea was to no avail. Yet, after the Ukrainians lost their freedom and territory, the Astral Domain of the Armed Forces did continue its existence metaphysically as a ghost (a mythological hologram) in legends and songs even during the long "Night of Statelessness" [3, p. 131]. It is noteworthy that Yevhen Malaniuk's lyric poetry also portrays the Domain of the National Armed Forces of Cossack Ukraine as something miragy, albeit imperishable, which is constantly addressing its descendants.

Just like in Poet idylii i "chornoi lzhy" (M. Rylskyi) (A Poet of Idyll and "Black Lie" (M. Rylskyi)) [1], Dmytro Dontsov stigmatized pro-Soviet artists for their servile humility and willingness to compromise in order to save their lives and preserve at least a slight possibility of pursuing their art, i.e. for their partial or absolute collaborationism, the author of Stylet $i$ stylos (A Stiletto and a Stylus) was well aware that if he had stayed in Ukraine, he himself would have hardly been able to choose a different path from the one his contemporaries did - unless of course he had committed suicide or been executed by the Stalinist regime. The poet directed his indignation not so much toward contemporary émigrés and by no means toward the submissive homo sovieticus. Ye. Malaniuk wrote these poems for the future, which, even if after long decades, as per the probability theory, would inevitably have to give new Ukrainian generations a chance of achieving real statehood. For Ye. Malaniuk, neither M. Rylskyi nor V. Sosiura were representative of the post-revolution Ukrainian literature, unlike Mykola Khvylovyi, about whom the author expressed many interesting thoughts in Notatnyky. To illustrate, "Khvylovyi's psyche was not colonial, but statehood-oriented" [4, p. 120], "Khvylovyi is a personality.., bigger than so-called ideologies" [4, p. 152], Khvylovyi's is "a furious cry of an awakened slave" [4, p. 220]. Ye. Malaniuk also explored the writing manner of this brilliant representative of Executed Renaissance. It might seem that to a certain extent Volodymyr Vynnychenko's vociferous criticism of the previously prohibited issues was consonant to that of Mykola Khvylovyi. However, what Vynnychenko regarded as manipulation, entertainment, explicit depravity, or decadence was seen by Khvylovyi as a national tragedy and a personal drama. Malaniuk's recognition of Khvylovyi as "a Ukrainian of a new, revolutionary, type" [4, p. 26], an artist who was able to overcome the complex of Little Russianism, is extremely important for us since the "nationally half-blooded" [6, p. 28] souls of 
Ukrainian artists, according to Malaniuk, also stem from the carcinogenic nature of Little Russianism. In order to prevent the actual and fictitious "descendants of the great past" from becoming skin-changers, freaks, and wet-stouts" [7, p. 43], modern Ukrainians must closely scrutinize the literature of the 20th century: demiurgic endeavors are by no means all divine by nature - the possibility of a satanic mission may well become a reality.

Malaniuk closely examines the creative oeuvre of Ivan Franko, Lesia Ukrainka, as well as that of some controversial personalities who were Ukrainians by descent yet with a Little Russian mentality, for instance Mykola Hohol and Volodymyr Vynnychenko. Worthy of notice is V. Panchenko's opinion that Ye. Malaniuk "viewed literature from the perspective of the nation-forming potential of the Word. And this is another broad theme in Malaniuk's diaries: literature, art as a manifestation of the spirit of a person and a nation" [13].

Malaniuk's arguments and conclusions are always thoroughly convincing. Well, who cares that the young Hohol constantly used the word Katsapiia* instead of Russia and called Ukraine Hetmanshchyna* reproaching M. Maksymovych for his leanings towards Moscow, which the author of Vechera na khutore bliz Dikanki (Evenings on a Farm near Dykanka) found disgusting first and foremost because it reminded him of "an old fat-bellied woman, from whom you can only smell shchi*** and hear swearing, that's it" [12, p. 10]? Who cares that Hohol's Revizor (The Government Inspector) came as a loud slap in the ugly fat face to the Russian bureaucratic system? Whoever cares that the reviews of both this comedy and Mertvi Dushi (Dead Souls) were far from laudative; a character from Mertvi Dushi, a Russian man named Nozdrev, was described as the most wicked caricature of a typical Russian nobleman; and the critic Feofil Tolstoi, who was no less popular than V. Bielinskii, was outraged to discover that Hohol's literary piece did not have "a single khokhol ${ }^{* * *+}$, as mean as Nozdrev". Afterwards, the critic went on to castigate him in the press. His article in Russkaia Starina (Russian Antiquity) had it that "Hohol showed all Russians in a filthy light" [13, p. 7]. In fact, the author of Revizor and Mertvi Dushi was very nervous about the critic's reaction: "Everyone is against me... Cursing me... I can guess what would have happened had I mentioned something about the life of Petersburgh" [9, p.3]. M. Hohol was a genius only during the Ukrainian period of his literary career. Paralyzed with the fear of the monstrous empire, Hohol became meek and submissive: his servile desire to become Russian gained the upper hand; he abandoned the plan to write about Ivan Mazepa and destroyed the second volume of Mertvi Dushi. On top of that, he emigrated to Italy to escape from himself - now Russified and totally alien to his own soul. According to Ye. Malaniuk, "the split Hohol was tragically looking for ... his 'fatherland's souls'" [10, p. 6]; and T. Salyha is of the opinion that Hohol's descending literary path turned into "the most terrible variant of Faust selling his soul to the devil" [12, p. 10]. Drawing on Ye. Malaniuk's judgements, T. Salyha makes an unexpected, albeit extremely insightful, conclusion that even though M. Hohol's works laid the foundation for Russian literary art, he also stifled "that Apollonian (classical and French in origin) poetry of Pushkin and his pleiad" [12, p. 10]. In Ye. Malaniuk's Notatnyky, there are startling revelations and conclusions: Hohol laid the foundation for the Russian prose; and Grzybowski, who became Griboedov in Russia, a firm foundation for the Russian theater [4, p. 173]. Moreover, it follows from Ye. Malaniuk's conclusions about V. Vynnychenko's oeuvre that the poet also regards him as an extinguisher of Ukrainian literature. Ye. Malaniuk's criticisms of V. Vynnychenko's works are scathing, albeit constructive. Interestingly, Oles Honchar gives an analogous feedback on the late 20thcentury postmodernist literature by referring to it as "a poisonous chemical".

National mentality manifests itself most vividly in the conceptions of talented artists; consequently, dysfunctional mentality, in dysfunctional conceptions. Yevhen Malaniuk demonstrates Volodymyr Vynnychenko's "innovativeness" as a representative example this kind of phenomenon: "The sullenly pigfaced directedness downwards, into dust, into mud. Vynnychenko's 'novels' keep one from thinking about height, about the sky... 'Morality is pink powder on the laws of nature'... And here, Nietzsche would have

\footnotetext{
Transl. note: katsapiia is a transliteration of the Ukrainian derogatory term for Russia; it is derived from katsapy, which is a transliteration of the Ukrainian for "long-bearded goats"; hence the degrading meaning of katsapiia - "the land of long-bearded goats".

** Transl. note: Hetmanshchyna is a transliteration of the Ukrainian for "the hetman state", with hetman being the head of the Cossack state.

${ }_{* * * *}^{* * *}$ Transl. note: shchi is a Russian cabbage soup.

Transl. note: The word khokhol refers to a long lock of hair left hanging from the top a shaven head, which was a common haircut of Ukrainian Cossacks; Ukrainians used the term among themselves as a form of ethnic identification; it is also used as a derogatory name for Ukrainians.
} 
started crying out of jealousy... Vynnychenko is not an individuality but a type, a type of Russian nature, and on top of that, in Ukraine..." [2, p. 16-17]. Hence comes the conclusion that M. Hohol harmed Russian literature as much as V. Vynnychenko harmed Ukrainian literature. Undoubtedly, one might try to provide reasons and examples to refute these claims; however, an opinion such as that of Malaniuk will not disappear anyway!

As regards Lina Kostenko, Yevhen Malaniuk aptly notes that the adversities of World War I, the revolution, the civil war programmed artists such as M. Zerov, H. Narbut, Yu. Yanovskyi, B. AntonenkoDavydovych, M. Bazhan, V. Pidmohylnyi, as well as Lina Kostenko, whose literary activity began a much later than theirs, for spiritual sovereignty: "Ukraine in the hearts and the mind" [4, p. 220]. The repressive system could not forgive the Ukrainian artists for that.

\section{CONCLUSIONS}

The phenomenon of Yevhen Malaniuk the poet and essayist is astonishing. In our literary art, we have a unique, extremely significant phenomenon, whose role has not been duly appreciated hitherto. As a myth-maker, as well as the founder of both the ideological political and the consolidating literary myth, this artist is not simply a bright figure in a cohort of the like-minded, but an exceptional Ukrainian intellectual and prophet of the 20th century.

\section{REFERENCES}

[1] Донцов Д. Поет ідилії і „чорної лжі” (М. Ридьський). В: Донцов Д. Дві літератури нашої доби. Гомін України, Торонто, 1958, 19-123.

[Dontsov D. Poet idylii i "chornoi lzhi" (M. Rylskyi). In: Dontsov D. Dvi literatury nashoi doby. Homin Ukrainy, Toronto, 1958, 19-123.]

[2] Маланюк Є. Буряне поліття. В: Маланюк Є. Книга спостережень. Атіка, Київ, 1992, 11- 27.

[Malaniuk Ye. Buriane polittia. In: Malaniuk Ye. Knyha sposterezhen. Atika, Kyiv, 1992, 11-27.]

[3] Маланюк Є. Нариси з історії нашої культури. В: Маланюк Є. Книга спостережень. Атіка, Київ, 1992, 85-141.

[Malaniuk Ye. Narysy z istorii nashoi kultury.In: Malaniuk Ye. Knyha sposterezhen. Atika, Kyiv, 1992, 85-141.]

[4] Маханюк Є. Нотатники (1936 - 1968): Документально-художне видання. Темпора, Київ, 2008. [Malaniuk Ye. Notatnyky (1936 - 1968): Dokumentalno-khudozhnie vydannia. Tempora, Kyiv, 2008.]

[5] Маланюк Є. Поезії. Український письменник, Київ, 1992.

[Malaniuk Ye. Poezii. Ukrainskyi pysmennyk, Kyiv, 1992.]

[6] Маланюк Є. Ранній Шевченко. В: Маланюк Є. Книга спостережень. Атіка, Київ, 1992, 27-35.

[Malaniuk Ye. Rannii Shevchenko. In: Malaniuk Ye. Knyha sposterezhen. Atika, Kyiv, 1992, 27-35.]

[7] Маланюк Є. Три літа. В: Маланюк Є. Книга спостережень. Атіка, Київ, 1992, 35-44.

[Malaniuk Ye. Try lita. In: Malaniuk Ye. Knyha sposterezhen. Atika, Kyiv, 1992, 35-44.]

[8] Мисюра Ф. Микола Гоголь в гадяцьькій ратуші. Літературна Україна, 13 червня (2002), 3.

[Mysiura F. Mykola Hohol v hadiatskii ratushi. Literaturna Ukraina, 13 chervnia (2002), 3.]

[9] Наєнко М. Національна ідентичність: Проблема філософська і філологічна. Пітературна Україна, 14 січня (1999), 6.

[Naienko M. Natsionalna identychnist: Problema filosofska i filolohichna. Literaturna Ukraina, 14 sichnia (1999), 6.]

[10] Панченко В. Шокова терапія від Євгена Маланюка. Режим достпу: http://litakcent.com/2008/02/25/volodymyr-panchenko-shokova-terapija-vid-jevhena-malanjuka/

[Panchenko V. Shokova terapiia vid Yevhena Malaniuka. Available at: http://litakcent.com/2008/02/25/volodymyr-panchenko-shokova-terapija-vid-jevhena-malanjuka/]

[11] Пушик С. Галич: Поезї. Молодь, Київ, 1990. 
[Pushyk S. Halych: Poezii. Molod, Kyiv, 1990.]

[12] Салига Т. Євген Маланюк: Художня ідентифікація Росії. Літературна Україна, 22 серпня (2002), 10. [Salyha T. Yevhen Malaniuk: Khudozhnia identyfikatsiia Rosii. Literaturna Ukraina, 22 serpnia (2002), 10.]

[13] Чемерис В. Загибель n'єси. Літературна Україна, 18 вересня (2003), 7.

[Chemerys V. Zahybel piesy. Literaturna Ukraina, 18 veresnia (2003), 7.]

Address: Olha Slonovska, Vasyl Stefanyk Precarpathian National University, 57 Shevchenko St., IvanoFrankivsk, 76025 Ukraine.

E-mail: olha.slonovska@ukr.net

Received: May 19, 2020; revised: October 22, 2020.

Слоньовська Ольга. "Як в нації вождя нема, тоді вожді їі - поети" (Українська материкова дітература крізь міфологічну призму бачення Є. Маланюком). Журнал Прикарпатського університету імені Василя Стефаника, 7 (2) (2020), 69-76.

Євгена Маланюка прийнято вважати одним із чільних поетів української діаспори. Врешті, саме він започаткував вітаїстичний консолідуючий міф України в літературі XX століття у діаспорній літературі, яка продовжувала повноцінно існувати й розвиватися за рубежем як типове і повноцінне українське національне красне письменство епохи модернізму. Метафізична програма консолідуючого міфу України засобами художньої літератури метафізично перероджувала читачівреципієнтів українського походження за рубежем із "рабів у буй-турів". Іншими словами забезпечувала реальну появу потенційних пасіонаріїв, національно свідомих українців, які навіть в умовах існування тоталітарного СРСР виношували ідею Української державності й мріяли про соборну Україну не "в екзилі", а на питомих українських землях.

На території радянської України Євген Маланюк був забороненим письменником. При згадці про нього материкові критики обов'язково вживали епітет “фашист", а радянські поети, зокрема Володимир Сосюра, щоб заявити про вдасну вірнопідданість комуністичній партії, погрожували 3 ним обов' язково зустрітися “в бою”. Закономірно, що вітаїстичний консолідуючий міф України навіть в обсязі одних лише Маланюкових поезій пересічним читачам був абсолютно не доступним. Проте на початку 90-х років XX ст., коли під час Референдуму не тільки генетичні українці, а й громадяни інших національностей, які проживали на території України, проголосували за незалежність і протягом наступних 20-и років неодноразово відстоювали Українську державу мирно й збройно, Євген Маланюк виявився одним із найбільш затребуваних поетів. Його вірші увійшли в шкільну програму 3 української літератури для старших класів, творчість стала об'єктом дослідження кандидатських і докторських дисертацій.

Врешті, Євген Маланюк був не тільки відомим поетом, не тільки унікальним ідеологом і політологом, а й талановитим критиком і літературознавцем. Уже всередині XX ст. у критичних і літературознавчих працях цей науковець користувався інструментарієм методології міфологізму, яка на той час у передових колах літературознавців Західної Європи і Америки була особливо популярною, але в материковій Україні абсолютно не відомою з причини "залізної завіси", яка унеможливлювала будь-які інтегральні процеси.

Міфологічне мислення Маланюка-лірика, Маланюка-історіографа, Маланюка-есеїста й Маланюка-літературознавця спричинилося до кардинально іншої обсервації української материкової культури й літератури того часу, ніж ці явища трактували радянські критики й науковці. Маланюк мав сміливість вести мову про те, про що не тільки було заборонено й згадувати в СРСР, а навіть про те, що самі українці намагалися обминути й у діаспорі, як ганебне або недолуге в нашій національній історії. Його висновки про помилки й прорахунки Хмельницького, I. Мазепи, М. Грушевського, 
С. Петлюри аж ніяк не виявилися загорнутими в барвисті папірчики сододкої брехні, цнотдивосором'яздивого утаювання від реципієнтів гіркої історичної правди.

Коли ж Євген Маланюк приступав до фахового аналізу літературного процесу в Радянській Україні й оцінки здісного перекручення радянськими дітературознавцями ідейно-тематичного наповнення художніх текстів так званого “дожовтневого періоду", його справедливому гніву не будо меж. Саме “залізних імператор строф" заговорив про звульгаризованого Шевченка, про вишукування в радянські часи у віршах цього українського генія не тільки того, що там ніколи не було, а й того, що апріорі навіть бути не могло. Маланюкові висновки про значення в українському красному письменстві І. Франка та Лесі Українки виявилися суголосними з сучасним прочитанням їхньої творчої спадщини.

Є. Маланюк феноменально зробив належні порівняльні аналізи творчості провідних українських письменників із напрацюваннями зарубіжних, застосовуючи зіставлення й методологію сучасної компаративістики. Він розкривав підтекстові змістовно-смислові компоненти віршів О.Пушкіна, М. Светлова, вказуючи на шовінізм як прикмету Росії та ії громадян у цілому, починаючи від останніх пияків і закінчуючи геніями.

Критичне ставлення цього дітературознавця до М. Гоголя й В. Винниченка також не є безпідставним. Належна аргументація висновків $Є$. Маланюком і в цьому випадку наукова й усебічна.

Стосовно Ліни Костенко, то Євген Маланюк не тільки повів мову про доречність повторення загальновідомих слів І. Франка про Лесю Українку і “всю соборну Україну”, а й нагадав реципієнтам своєї статті, що екстремальні події Другої світової війни, як і фатальне фіаско Першої світової, революція, громадянська війна запрограмували появу таких митців, як М. Зеров, Г. Нарбут, Ю. Яновський, Б. Антоненко-Давидович, М. Бажан, В. Підмогидьний, а також значно пізнішу від них у часі (60-і роки) реалізацію творчого потенціалу Діну Костенко на вроджену духовну суверенність $\mathrm{i}$ національну самоідентифікацію всупереч догмам тоталітарної комуністичної ідеології.

Є. Маланюк справді був і залишається духовним вождем як українців за кордоном так і метафізично й уже тільки на перспективу - материкових синів і дочок України сьогоднішньої.

Кдючові слова: концепція України, державна свідомість, національна ідея, національна ментальність, російський імперіалізм, міфологічне мислення, українська культура, літературознавча есеїстика. 